\title{
Perception of community pharmacists about the work process of drug dispensing: a cross-sectional survey study
}

Sabrina Cerqueira-Santos ${ }^{1,2}$, Kérilin Stancine Santos Rocha², Dyego Carlos Souza Anacleto de Araújo², Elindayane Vieira de Souza ${ }^{1,2}$, Lara Joana Santos Caxico Vieira² ${ }^{2}$ Sylmara Nayara Pereira dos Santos ${ }^{2}$ and Divaldo Pereira de Lyra Júnior ${ }^{1,2^{*}}$

\begin{abstract}
Background: Drug dispensing aims to promote rational medicine use. However, in many countries, the work processes are still not well defined. In this sense, the perception of pharmacists about dispensing practices presents an overview of how the service is being performed in the country and its main challenges. Thus, the purpose of this study was to determine the self-reported work process of Brazilian community pharmacists in relation to drug dispensing, challenges, and strategies for carrying out the service.

Method: A cross-sectional survey was conducted between May and July 2021, with community pharmacists from all regions of Brazil. Pharmacists were invited to answer a validated, self-administered questionnaire, implemented through Google Forms, containing 33 questions related to the steps of drug dispensing (questions and counseling) and the main challenges and strategies to perform the service. The data were exported to Microsoft Office Excel and SPSS ${ }^{\circledR}$. Multiple linear regression analysis was used to assess the association between responses and demographic information, with a significance level of less than $5 \%(p<0.05)$. This study was approved by the Research Ethics Committee (number: 4.295.171).

Results: A total of 625 community pharmacists responded to the survey. Most pharmacists reported always or frequently performing 17 (54\%) of the 31 steps described in the instrument. The steps that pharmacists reported performing more frequently were forming the medication name $(n=569,91.04 \%)$, verifying the completeness and adequacy of the prescription according to current legislation $(n=567,90.72 \%)$ and providing counseling on dosage $(n=549,87.84 \%)$. Documentation was the main step in which pharmacists reported never or rarely performing $(n=424,67.84 \%)$. The results showed that there was a significant influence of the variables of public education institution, age, and postgraduate education on the frequency of dispensing steps $(F(3,621)=14.884, p<0.001$; $\left.R_{\text {ajdusted }}^{2}=0,063\right)$.
\end{abstract}

Conclusion: This study showed that most pharmacists reported always or frequently asking most of the questions and performing counseling contained in the instrument during drug dispensing. These results can contribute to an understanding of current dispensing practices and generate insights for developing strategies to qualify the service.

\footnotetext{
*Correspondence: lepfs.ufs@gmail.com

${ }^{2}$ Laboratory of Teaching and Research in Social Pharmacy (LEPFS),

Department of Pharmacy, Federal University of Sergipe, Avenue Marechal

Rondon, Jd. Rosa Elze, São Cristóvão, Sergipe Zip code 49100-000, Brazil

Full list of author information is available at the end of the article
}

(C) The Author(s) 2022. Open Access This article is licensed under a Creative Commons Attribution 4.0 International License, which permits use, sharing, adaptation, distribution and reproduction in any medium or format, as long as you give appropriate credit to the original author(s) and the source, provide a link to the Creative Commons licence, and indicate if changes were made. The images or other third party material in this article are included in the article's Creative Commons licence, unless indicated otherwise in a credit line to the material. If material is not included in the article's Creative Commons licence and your intended use is not permitted by statutory regulation or exceeds the permitted use, you will need to obtain permission directly from the copyright holder. To view a copy of this licence, visit http://creativecommons.org/licenses/by/4.0/. The Creative Commons Public Domain Dedication waiver (http://creativeco mmons.org/publicdomain/zero/1.0/) applies to the data made available in this article, unless otherwise stated in a credit line to the data. 
Keywords: Community pharmacy services, Pharmaceutical services, Pharmacies, Drug dispensing. Survey

\section{Background}

Worldwide, community pharmacies are considered the main health establishments that provide access to medicines for the population. In the United States, in 2019, approximately 4.38 billion prescriptions were dispensed [1]. In Brazil, this number may be even higher, since this country is one of the five largest medicine consumers in the world [2]. Furthermore, there are more than 85 thousand community pharmacies in the country, which is considered the workplace of almost $80 \%$ of Brazilian pharmacists [3, 4].

In Brazil, people have access to medicines through private community pharmacies and/or pharmacies belonging to the Brazilian Health System (SUS), free of charge. Nationally regulated licensure is needed to open and operate a community pharmacy in Brazil. Although pharmacy ownership is not restricted to pharmacists, a legally responsible pharmacist should be employed and be everpresent at the pharmacy during opening hours. There are no rules regarding the location of pharmacies in Brazil in relation to demographic and geographical criteria $[5,6]$.

In this context, community pharmacists are the health professionals most accessible to the public [7]. During the coronavirus (SARS-COV2) pandemic, pharmacists screened patients with COVID-19, advising the population about the disease, the use of medications, and made referrals when appropriate $[8,9]$. Among the services that pharmacists can perform in community pharmacies, drug dispensing is a clinical pharmacy service that ensures the provision of medicines and other health products through the analysis of technical and legal aspects of prescription, assessment of individual health needs, and performance of interventions in the medicine use process, which includes pharmaceutical counseling and documentation of interventions made [10-12].

Drug dispensing, when performed properly, promotes the rational use of medicines, providing effective and safe treatments, and improving the patient's quality of life $[13,14]$. However, although it is a service traditionally performed by pharmacists, there are still difficulties in understanding the drug dispensing by pharmacists, and other professionals, and the work processes of this service are not well defined $[15,16]$. Studies performed in low-to middle-income countries, including Brazil, show that drug dispensing is often performed with insufficient counseling to patients and most of the time there is no record of the patient's information and the interventions performed $[17,18]$. As a result, the quality of care provided can be affected, compromising the medication use process.

In Brazil, self-reported studies have assessed pharmacists' knowledge of drug dispensing, focusing on regulatory aspects and studies that generally concern activities carried out by community pharmacists [3, 19-21]. However, studies on drug dispensing practices at the national level are still scarce and can present an overview of how the service is being carried out in the country and its main challenges. Thus, the objective of this study was to determine the self-reported work process of Brazilian community pharmacists in relation to drug dispensing, the challenges, and strategies for carrying out the service.

\section{Methods Study design}

A cross-sectional survey was conducted in Brazil, between May and July 2021, using the recommendations proposed by Kelley (2003) [22], Bennett et al. (2011) [23], and Rybakov et al. (2020) [24]. All methods were carried out in accordance with relevant guidelines and regulations.

\section{Questionnaire development}

The questionnaire used in this study was developed by two researchers (KSSR; SCC), through meetings, based on instruments validated by Rocha et al. (2020) [25] and Cerqueira-Santos et al. (2019) [26]. The content validity of the questionnaire was performed using the Delphi technique. Thus, a panel of six experts in drug dispensing from Brazil, including three researchers and three pharmacists were invited to participate in Delphi, following literature recommendations [27]. The experts were selected based on the adaptation of Fehring's scoring model. A minimum score of five points was required to warrant selection [28].

In the first round of the Delphi, the experts were informed about the study's aims and the instructions necessary to carry out the content validity assessment. An electronic assessment form was sent via email to the experts. They were asked to rate each item using the following criteria: simplicity (the content of the item expresses a single idea), language clarity (i.e., the language is clear, understandable, and appropriate for the target population), and practical pertinence (i.e., the item assesses a concept that is of interest to the target population), using a 5-point Likert scale. The experts were also invited to provide additional comments about each questionnaire item. The content validity coefficient $(\mathrm{CVC})$ 
was calculated to quantify content validity. The cutoff score was used to indicate a satisfactory level of simplicity, language clarity, and practical pertinence was $\geq 0.80$ (for each item and the entire scale) [29]. The deadline for the evaluation and judgment of the items was 30 days, with weekly reminders sent via e-mail.

During the second round, the expert panel had access to all the results obtained during the first round. The expert panel was instructed to analyze changes in items and evaluate them according to the criteria (simplicity, language clarity, and practical pertinence), using the 5-point Likert scale. The content validity coefficient was calculated to quantify the content validity. The cutoff score used was $\geq 0.80$ (for each item and the entire scale). The deadline for evaluation and judgment of items was 30 days, and weekly reminders were sent to the expert panel members by e-mail. After content validity, a pilot test was carried out to evaluate the clarity, comprehension, and time of completion of the questionnaire with 10 purposely selected community pharmacists who were excluded from the final survey.

\section{Survey application}

\section{Sample selection/participants}

A convenience sample and snowball strategy were used to select participants [22]. The study included pharmacists who work in community pharmacies, performed drug dispensing in their routine practice, of both sexes, and who agreed to voluntarily participate in the research. In this study, there were no exclusion criteria.

\section{Data collection}

The anonymous, self-administered questionnaire was sent to pharmacists in all regions of Brazil through an online platform (Google Forms) between May and July 2021. The invitation to pharmacists to participate in the research was advertised through social media and in partnership with Brazilian Regional Pharmacy Council through email and websites. Upon accessing the online platform, only community pharmacists were instructed to respond to the survey. All questions in the questionnaire were marked as mandatory to avoid incomplete answers. No financial incentives were provided to the participants.

\section{Sample size calculation}

Considering a population of 221.258 pharmacists registered with the Regional Pharmacy Councils in 2020 in Brazil [4], a confidence level of $95 \%$ and a sampling error of $5 \%$, a minimum of 384 pharmacists were required for this study.

\section{Data analysis}

The data were presented using descriptive statistics (mean, standard deviation, and percentage). We assumed a normal distribution of data based on skewness $(-.223)$ and kurtosis (-.147) measures. A multiple linear regression analysis (forward method) was performed to investigate the variables: sex, age, time since graduation, graduate institution, postgraduate education, type of postgraduate degree (stricto sensu or lato sensu), experience with drug dispensing, workplace, and the frequency of the drug dispensing steps. It is worth noting that the the stricto sensu postgraduate course refers to the master's and $\mathrm{PhD}$ programs. The lato sensu postgraduate programs comprise specialization programs with a minimum workload of $360 \mathrm{~h}$, including, for example, MBA (Master Business Administration) and residency program. For the statistical analysis, a total score was established for the frequency of steps performed by the pharmacist during drug dispensing, with 1 point representing "never," 2 "rarely," 3 "sometimes," 4 "often" and 5 "ever." The minimum score was 31 and the maximum score was 155 points. The data from the online survey were exported into Microsoft Office Excel and SPSS ${ }^{\circledR}$ (version 22.0). Missing data were handled using a single imputation [30].

\section{Results}

Survey instrument development

Of the six experts invited to compose the panel of experts, six returned their assessments $(100 \%$ rate of return). Half of the experts were between 31 and 40 years of age $(n=3)$. Their mean professional experience with drug dispensing was $8.33 \pm 4.03$ years. Half of the experts had a $\mathrm{PhD}(n=3,50 \%)$ and specialized in a clinical area $(n=3,50 \%)$, such as Clinical Paharmacy and Pharmaceutical Care. In first round of the Delphi, with all the three criteria, the questionnaire yielded coefficients $\geq 0.80$ (range $=0.87-1.0)$. Only one item obtained a coefficient of 0.70 for the clarity criterion and has been resubmitted for review. Although most items achieved a $C V C \geq 0.80$, some suggestions were relevant and resulted in item changes. The main suggestions were related to changes in the writing of some items and the division of some questions. Of the six experts who participated in the first round, five completed the second round $(83,33 \%$ rate of return). For all three criteria, the questionnaire yielded coefficients that were $\geq 0.80$ (range $=0.85-1.0$ ), thus generating the final version of the questionnaire.

The questionnaire was divided into the following sections: i) pharmacists' perceptions about the work process of drug dispensing (31 items), ii) strategies and challenges for performing drug dispensing ( 2 items), and iii) 
sociodemographic data. The items in the first section refers to the steps (questions and counseling) that can be performed during drug dispensing. The survey items were answered using a 5-point Likert scale ranging from never to always and multiple-choice questions. When appropriate, an additional free text area was provided (Additional file 1).

\section{Survey application}

A total of 625 community pharmacists responded to the survey. It was not possible to calculate the response rate because of the survey's multiple means of dissemination. Of this sample, $72.96 \%(n=456)$ were female, the mean age of pharmacists was $33 \pm 7.44$ years, and the average time since pharmacy graduation was $6.22 \pm 6.21$ years. Of the 273 pharmacists who completed a postgraduate course in the clinical area, 254 (91.69\%) had done a lato sensu postgraduate course. The characteristics of these professionals are presented in Table 1.

The frequency with which pharmacists reported performing some steps of the drug dispensing service is described in Table 2. Most professionals reported always or frequently performing $17(54.00 \%)$ of the 31 steps described in the instrument. The average score for the frequency of steps performed by the pharmacist during dispensing was $112 \pm 20$ points (54-155). Item 7 (inform the medicine name) was the item that pharmacists reported performing most frequently (always or frequently) ( $n=569,91.04 \%)$, followed by item 1 (verifying the completeness and adequacy of the prescription according to current legislation) $(n=567,90.72 \%)$, item 14 (counsel on dosage) $(n=549,87.84 \%)$, item 2 (verifies whether the drug dispensing is for the patient, caregiver, or other person) ( $n=534,85.44 \%$ ), and finally item 12 (counsel on how to use the pharmaceutical form of the medicine) ( $n=497,79.752 \%)$.

The dispensing steps that pharmacists reported to be rarely or never performing were related to item 30 (Documents the interventions performed in the drug dispensing) $(n=424,67.84 \%)$, followed by item 21 (counsel on medicine disposal) $(n=274,43.84 \%)$ and 22 (Verify if the patient knows about aspects related to the treatment safety) ( $n=209,33.44 \%)$ and 16 (counsel on time for the medicine to take effect) $(n=169,27.04 \%)$.

The results showed that there is a significant influence of the predictor variables of public graduate institution, increasing age and postgraduate on the frequency scores of the dispensing steps $(\mathrm{F}(3.621)=14.884, p<0.001$; R2adjusted $=0.063$ ). Table 3 presents the coefficients for all significant predictor variables. The variable that most strongly impacted the scores was public graduate institution, explaining $4.6 \%$ of the outcome. The other variables were related to only $1.9 \%$ of the score variance. The
Table 1 Characteristics of pharmacists who responded the survey $(n=625)$

\begin{tabular}{|c|c|}
\hline Characteristics & Pharmacists (\%) \\
\hline \multicolumn{2}{|l|}{ Sex } \\
\hline Female & $456(72.96 \%)$ \\
\hline Male & $169(27.04 \%)$ \\
\hline \multicolumn{2}{|l|}{ Age } \\
\hline 21-30years & $286(45.76 \%)$ \\
\hline $31-40$ years & $252(40.32 \%)$ \\
\hline More than 40years & $87(13.92 \%)$ \\
\hline \multicolumn{2}{|l|}{ Time since graduation } \\
\hline Up to1 year & $84(13.44 \%)$ \\
\hline From 2 to 4 years & $256(40.96 \%)$ \\
\hline From 5 to 7 years & $112(17.92 \%)$ \\
\hline More than 7 years & $173(27.68 \%)$ \\
\hline \multicolumn{2}{|l|}{ Graduate institution } \\
\hline Public & $215(34.40 \%)$ \\
\hline Private & $410(65.60 \%)$ \\
\hline \multicolumn{2}{|l|}{ Workplace ${ }^{\mathrm{a}}$} \\
\hline Private community pharmacy chain & $422(67.52 \%)$ \\
\hline Independent community pharmacy & $149(23.84 \%)$ \\
\hline Public pharmacy & $102(16.32 \%)$ \\
\hline \multicolumn{2}{|l|}{ Postgraduate in the clinical area } \\
\hline Yes & $273(43.68 \%)$ \\
\hline No & $352(56.32 \%)$ \\
\hline \multicolumn{2}{|l|}{ Time that works with dispensing (years) } \\
\hline Up to1 year & $157(25.12 \%)$ \\
\hline From 2 to 4 years & $229(36.64 \%)$ \\
\hline From 5 to 7 years & $85(13.60 \%)$ \\
\hline More than 7 years & $154(24.64 \%)$ \\
\hline \multicolumn{2}{|l|}{ Brazil region } \\
\hline Northeast & $359(57.44 \%)$ \\
\hline Southeast & $112(17.92 \%)$ \\
\hline South & 74 (11.84\%) \\
\hline Midwest & $67(10.72 \%)$ \\
\hline North & $13(2.08 \%)$ \\
\hline
\end{tabular}

${ }^{a}$ The pharmacist can work in more than one location

variables time since graduation, workplace, type of postgraduate degree, years of experience with dispensing and sex had no significant impact $(p<0.05)$ (Table 4$)$.

Pharmacists used different strategies for patient counseling during drug dispensing and most of them reported using more than one strategy $(n=528,84.48 \%)$ (Table 5). The main strategy was verbal information $(n=611,97.76 \%)$, followed by written information $(n=412,65.92 \%)$. The main challenges in performing drug dispensing are described in Table 6, with the most reported being the large number of patients using the community pharmacy ( $n=494,79.04 \%)$, refusal of counseling by the patient because they had already been 
Table 2 Frequency with which the steps are performed by pharmacists during drug dispensing $(n=625)$

\begin{tabular}{|c|c|c|c|c|c|}
\hline \multirow[t]{2}{*}{ Steps } & \multicolumn{5}{|c|}{ Frequency with which the pharmacist performs step $\mathrm{n}(\%)$} \\
\hline & Always & Frequently & Sometimes & Rarely & Never \\
\hline $\begin{array}{l}\text { 1.Verify the completeness and adequacy of the prescription } \\
\text { according to current legislation }\end{array}$ & $412(65.92 \%) *$ & $155(24.80 \%)$ & $45(7.20 \%)$ & $11(1.76 \%)$ & $2(0.32 \%)$ \\
\hline $\begin{array}{l}\text { 2.Verify if the dispensing is for the patient, caregiver, or other } \\
\text { person }\end{array}$ & $308(49.28 \%) *$ & $226(36.16 \%) *$ & 75 (12.00\%) & $12(1.92 \%)$ & $4(0.64 \%)$ \\
\hline 3. Verify if this is the first time the patient uses the medicine & $157(25.12 \%)$ & $253(40.48 \%) *$ & $173(27.68 \%)$ & $36(5.76 \%)$ & $6(0.96 \%)$ \\
\hline $\begin{array}{l}\text { 4. Verify if there are contraindications for the use of the medicine } \\
\text { (e.g., allergy, pregnancy, health conditions, among others) }\end{array}$ & $129(20.54 \%)$ & $210(33.60 \%)$ & $200(32.00 \%)$ & $76(12.16 \%)$ & $10(1.60 \%)$ \\
\hline $\begin{array}{l}\text { 5.Verify if the patient uses other medications or has other health } \\
\text { problems }\end{array}$ & $93(14.88 \%)$ & $186(29.76 \%)$ & $231(36.96 \%) *$ & $102(16.32 \%)$ & $13(2.08 \%)$ \\
\hline $\begin{array}{l}\text { 6. Verify if the patient is familiar with the indication(s) of the } \\
\text { medication }\end{array}$ & $126(20.16 \%)$ & $220(35.20 \%)^{*}$ & $202(32.32 \%)$ & $73(11.68 \%)$ & $4(0.64 \%)$ \\
\hline 7. Inform the medication name & $431(68.96 \%) *$ & $138(22.08 \%)$ & $40(6.40 \%)$ & $11(1.76 \%)$ & $5(0.80 \%)$ \\
\hline $\begin{array}{l}\text { 8. Counsel on the clinical condition (disease/sign/symptom) for } \\
\text { which the medication was prescribed }\end{array}$ & $125(20.00 \%)$ & $257(41.12 \%) *$ & $182(29.12 \%)$ & $53(8.48 \%)$ & $8(1.28 \%)$ \\
\hline 9. Counsel about medication indication(s) & $196(31.36 \%)$ & $243(38.88 \%) *$ & $153(24.48 \%)$ & $28(4.48 \%)$ & $5(0.80 \%)$ \\
\hline 10. Counsel on therapeutic goals & $75(12.00 \%)$ & 169 (27.04\%) & $214(34.24 \%)$ & $127(20.32 \%)$ & $40(6.40 \%)$ \\
\hline 11. Verify if the patient knows about correct use of the medication & $193(30.88 \%)$ & $218(34.88 \%)$ & $163(26.08 \%)$ & $43(6.88 \%)$ & $8(1.28 \%)$ \\
\hline $\begin{array}{l}\text { 12. Counsel on how to use the pharmaceutical form of the } \\
\text { medication }\end{array}$ & $281(44.96 \%) *$ & $216(34.56 \%)$ & $106(16.96 \%)$ & $20(3.20 \%)$ & $2(0.32 \%)$ \\
\hline 13. Inform the route of administration of the medication & $310(49.60 \%) *$ & $177(28.32 \%)$ & 97 (15.52\%) & $36(5.76 \%)$ & $5(0.80 \%)$ \\
\hline $\begin{array}{l}\text { 14. Counsel on dosage (dose, frequency, and duration of treat- } \\
\text { ment) }\end{array}$ & $338(54.08 \%) *$ & $211(33.76 \%)$ & $61(9.76 \%)$ & $14(2.24 \%)$ & $1(0.16 \%)$ \\
\hline 15. Counsel about the time to take the medication & $296(47.36 \%) *$ & $204(32.64 \%)$ & $103(16.48 \%)$ & $18(2.88 \%)$ & $4(0.64 \%)$ \\
\hline 16. Counsel on time for the medication to take effect & $93(14.88 \%)$ & $140(22.40 \%)$ & $223(35.68 \%) *$ & $148(23.68 \%)$ & $21(3.36 \%)$ \\
\hline 17. Counsel on interactions (drug/drug; drug/food; drug/alcohol) & $79(12.64 \%)$ & $159(25.44 \%)$ & $227(36.32 \%) *$ & $136(21.76 \%)$ & $24(3.84 \%)$ \\
\hline 18. Counsel on how to monitor the health problem & $66(10.56 \%)$ & $178(28.48 \%)$ & $215(34.40 \%)$ & $139(22.24 \%)$ & $27(4.32 \%)$ \\
\hline 19. Counsel on non-pharmacological treatment & $82(13.12 \%)$ & $178(28.48 \%)$ & $239(38.24 \%) *$ & $96(15.36 \%)$ & $30(4.80 \%)$ \\
\hline 20. Counsel on medication storage & $126(20.16 \%)$ & $170(27.20 \%)$ & $186(29.76 \%)$ & $115(18.40 \%)$ & $28(4.48 \%)$ \\
\hline 21. Counsel on medication disposal & $71(11.36 \%)$ & $105(16.80 \%)$ & $175(28.00 \%)$ & $199(31.84 \%)$ & $75(12.00 \%)$ \\
\hline $\begin{array}{l}\text { 22. Verify if the patient knows about aspects related to the treat- } \\
\text { ment safety (e.g., have you ever felt something different when } \\
\text { using this medication?) }\end{array}$ & $61(9.76 \%)$ & $110(17.60 \%)$ & $245(39.20 \%) *$ & $158(25.28 \%)$ & $51(8.16 \%)$ \\
\hline $\begin{array}{l}\text { 23. Counsel on precautions regarding the medication use (e.g., } \\
\text { for medications that cause drowsiness, pay extra attention when } \\
\text { driving or operating machinery) }\end{array}$ & $184(29.44 \%)$ & $221(35.36 \%) *$ & $148(23.68 \%)$ & $53(8.48 \%)$ & $19(3.04 \%)$ \\
\hline 24. Counsel on adverse drug reactions & $79(12.64 \%)$ & $161(25.76 \%)$ & $276(44.16 \%) *$ & $91(14.56 \%)$ & $18(2.88 \%)$ \\
\hline $\begin{array}{l}\text { 25. Counsel on the consequences of using the medication in the } \\
\text { long-term, when applicable }\end{array}$ & $129(20.64 \%)$ & $172(27.52 \%)$ & $212(33.92 \%)$ & $88(14.08 \%)$ & $24(3.84 \%)$ \\
\hline $\begin{array}{l}\text { 26. Verify if the patient is aware of aspects related to medication } \\
\text { adherence (e.g.: Some people forget to take their medication, } \\
\text { does this happen to you? What are your concerns regarding the } \\
\text { use of this medication?) }\end{array}$ & $92(14.72 \%)$ & $185(29.60 \%)$ & $204(32.64 \%)$ & $112(17.92 \%)$ & $32(5.12 \%)$ \\
\hline 27. Counsel on management in case of a missed dose & $81(12.96 \%)$ & $145(23.20 \%)$ & $217(34.72 \%)$ & $141(22.56 \%)$ & $41(6.56 \%)$ \\
\hline $\begin{array}{l}\text { 28. Counsel on the importance of correct use of medicine and } \\
\text { medication adherence }\end{array}$ & $215(34.40 \%)$ & $242(38.72 \%) *$ & $121(19.36 \%)$ & $38(6.08 \%)$ & $9(1.44 \%)$ \\
\hline $\begin{array}{l}\text { 29. Confirm the patient's understanding of the counseling pro- } \\
\text { vided in the drug dispensing }\end{array}$ & $199(31.84 \%)$ & $238(38.08 \%) *$ & $122(19.52 \%)$ & $52(8.32 \%)$ & $14(2.24 \%)$ \\
\hline $\begin{array}{l}\text { 30. Documents the interventions performed in the drug dispens- } \\
\text { ing }\end{array}$ & $66(10.56 \%)$ & $52(8.32 \%)$ & $83(13.28 \%)$ & $137(21.92 \%) *$ & $287(45.92 \%) *$ \\
\hline $\begin{array}{l}\text { 31. Refers the patient to other health professionals and/or clinical } \\
\text { pharmacy services, when necessary }\end{array}$ & $185(29.6 \%)$ & $162(25.92 \%)$ & $137(21.92 \%)$ & 94 (15.04\%) & $47(7.52 \%)$ \\
\hline
\end{tabular}

*Most frequently reported steps for each Likert scale level 
Table 3 Predictive variables of frequency scores of dispensing steps

\begin{tabular}{llllll}
\hline Variables & $\begin{array}{l}\text { Standardized } \\
\text { coefficients } \\
\text { Beta }\end{array}$ & $\boldsymbol{t}$ & Sig. & $\boldsymbol{R}^{2}$ & $\boldsymbol{\Delta} \boldsymbol{R}^{2}$ \\
\hline (Constant) & - & 25.792 & 0.000 & - & - \\
Public graduate institution & 0.213 & 5.491 & 0.000 & 0.046 & - \\
Age & 0.101 & 2.595 & 0.010 & 0.057 & 0.012 \\
Postgraduate & 0.086 & 2.213 & 0.027 & 0.063 & 0.007 \\
\hline
\end{tabular}

Table 4 Predictor variables excluded from the model

\begin{tabular}{llll}
\hline Predictors & Beta & $\boldsymbol{t}$ & Sig. \\
\hline Time since graduation (years) & -0.086 & -1.619 & 0.106 \\
Work in private community pharmacy chain & -0.001 & -0.030 & 0.976 \\
Work in independent community pharmacy & 0.021 & 0.544 & 0.587 \\
Postgraduate Stricto Sensu & -0.021 & -0.515 & 0.607 \\
Time that works with dispensing (years) & 0.066 & 1.451 & 0.147 \\
Sex (Female) & 0.070 & 1.787 & 0.074 \\
\hline
\end{tabular}

Table 5 Strategies used to patient counseling during drug dispensing $(n=625)$

Strategies for pharmacist's counseling during drug dispensing

Pharmacists (\%)

Verbal information

Written information

611 (97.76\%)

412 (65.92\%)

$358(57.28 \%)$

$143(22.88 \%)$

$183(29.28 \%)$

$66(10.56 \%)$

37 (5.92\%)

Table 6 Main challenges to perform drug dispensing $(n=625)$

\begin{tabular}{|c|c|}
\hline Challenges to perform drug dispensing & Pharmacists (\%) \\
\hline Large number of patients using the community pharmacy & $494(79.04 \%)$ \\
\hline View of the pharmacy as a commercial establishment & $312(49.92 \%)$ \\
\hline Provision of more than one medicine during dispensing & $205(32.80 \%)$ \\
\hline Absence of a semi-private place to carry out the drug dispensing & $276(44.16 \%)$ \\
\hline Limitation of knowledge and clinical skills for perform drug dispensing & $88(14.08 \%)$ \\
\hline No request for counseling by the patient & $283(45.28 \%)$ \\
\hline Refusal of counsel by the patient because he had already been counseled by the physician & $314(50.24 \%)$ \\
\hline
\end{tabular}

counseled by the physician $(n=314,50.24 \%)$, and the view of the pharmacy as a commercial establishment $(n=312,49.92 \%)$. Other challenges reported were lack tions, and as a result, provide the necessary counseling for rational medicine use [25, 36]. Therefore, 
understanding the process and the main challenges are essential to improve the service, enabling the design of specific strategies for each reality.

The results of this study showed a relationship between the graduate institution and the frequency with which questions were asked, and counseling was given according to pharmacists' reports. This difference had a small size effect, but studies have shown differences in pharmacy undergraduate institutions. In Brazil, there are approximately 429 pharmacy degree courses in private institutions and 73 courses public institutions, more than four times the number of degree courses in the United States [37]. Despite efforts to improve the clinical training of Brazilian pharmacists, such as the publication of the new Guidelines for the Undergraduate Course in Pharmacy that recommend that $50 \%$ of the workload of the course is in the healthcare lines, the unreasonable number of higher education institutions, different curricular structures, and teaching methods may have influenced the work process of drug dispensing [37-40].

Still on the subject of pharmacy undergraduate institutions, indicators related to student performance, faculty, and conditions offered for the development of the learning process showed that the quality of public institutions in Brazil is better than that of private institutions [41]. In contrast, countries like the United States, England, and Australia have accredited institutions that harmonize pharmacy education, providing higher quality and uniformity in higher education [42-44]. Thus, it is expected that Brazilian institutions, public or private, focus to the needs of society, in order to develop critical and competent professionals for the provision of clinical pharmacy services, such as drug dispensing.

Regarding postgraduate education in the clinical area, a significant difference was also observed in the frequency of questions and counseling during drug dispensing. Patient-centered care requires pharmacists to be involved in the continuous improvement of knowledge, skills, and performance $[45,46]$. According to the literature, some barriers prevent pharmacists from engaging in continuing education activities, such as the lack of specific policies, time, and motivation [45, 47, 48]. Some countries, such as the United States, have legislation mandating pharmaceutical continuing education for pharmacists' relicensure, which involves, for example, specification of a certain number of live and home study credit hours, and specific topic requirements [49]. In contrast, in Brazil, there is no requirement for annual accreditation hours for professional relicensure. Therefore, Brazilian institutions should be inspired by the example set by other countries to overcome these challenges, as well as to make pharmacists aware of the need for continuous improvement in the provision of patient care.
In this study, it was observed that the older the professionals, the more they reported questions asked and provided counseling to patients. According to the literature, counseling skills on medicine use can improve with age, and professionals can feel more confident in providing clinical pharmacy services in the health field [46, 50-52]. It is important to highlight that other factors were not evaluated in the statistical model of this study and can influence the counseling rates during drug dispensing, such as the complexity of the clinical case, lack of time, large number of patients using the community pharmacy, pharmacists' knowledge, and patients' attitudes, among others [53-55]. Therefore, it is necessary to be careful when analyzing the results, as age is not the only, or the most important, factor that can influence the process of drug dispensing.

Most pharmacists in this study reported not documenting drug dispensing. Documentation is an essential component of the care process, as it facilitates communication and enables the measurement of results $[56,57]$. In high-income countries, the documentation of interventions during drug dispensing is well consolidated, but there are factors that hinder this process in low- and middle-income countries, such as the reduced number of professionals in the pharmacy, lack of time, and little understanding of the importance of this component of practice $[56,58]$. Thus, teaching-learning strategies must be incorporated in both undergraduate and continuing education to develop, in students and professionals, the skills needed to overcome this main challenge in patient care [26]. In addition, changes in organizational culture are needed to encourage professionals to document their practices. The use of technologies such as big data and applications can facilitate the incorporation of drug dispensing documentation in Brazilian community pharmacies $[59,60]$.

In this study, the main challenges in dispensing reported by pharmacists were related to the large number of patients using the community pharmacy and the patient's behavior. Similar results have been described in the literature, and the most common barriers in providing patient counseling were patient factors, the large number of patients using the community pharmacy, and lack of professional hours available [15, 32, 61]. In addition, peak hours are associated with patient dissatisfaction, which can negatively affect their experience [62]. As many patients still do not understand the role of pharmacists in improving health outcomes, strategies such as the organization of drug dispensing work processes, the professional's proactive attitude, and the use of technologies can facilitate patient care during dispensing $[63,64]$.

This study had several strengths and limitations. The main limitation is that self-reported research may have 
generated socially desirable responses and did not reliably represent reality. Furthermore, as the representativeness of the sample could not be verified caution should be exercised in generalising these findings. To our knowledge, this is the first study carried out in different regions of a continental country such as Brazil that sought to understand the self-reported work process of Brazilian community pharmacists in relation to drug dispensing and the challenges and strategies for carrying out the service.

\section{Conclusion}

Most study participants reported performing most of the necessary questions and counseling during drug dispensing. The frequency of questions and counseling was influenced by factors such as the age of the pharmacist, the educational institution, and continuing education, such as postgraduate education. The present study observed problems existing in Brazilian drug dispensing practices, such as the large number of patients using the community pharmacy, refusal of counseling by the patient, and the view of the pharmacy as a commercial establishment, among others. The main strategies for pharmacists' counseling during drug dispensing were verbal and written information. The data obtained can contribute to understanding the current reality and generating insights for community pharmacists, researchers, health policy makers, and other stakeholders to optimize the work process of drug dispensing and its impact on patient outcomes.

\section{Abbreviation}

CVC: Content validity coefficient.

\section{Supplementary Information}

The online version contains supplementary material available at https://doi. org/10.1186/s12913-022-07528-y.

\section{Additional file 1.}

\section{Acknowledgements}

The authors thank the pharmacists who participated in the survey, the Regional Pharmacy Councils in Brazil and other collaborators who disseminated the research.

\section{Authors' contributions}

SCS, KSSR and DPLJ made substantial contributions to the conception or design of the work. SCS, SPS, EVS, and LJSCV made the acquisition of data. SCS, KSSR and DCSAA made the analysis, and interpretation of data. SCS, KSSR, and SPS have drafted the work. EVS, LJSCV, DCSAA and DPL reviewed and provided important contributions to the structure and content of the manuscript. . The authors read and approved the final manuscript.

\section{Funding}

This study was financed in part by the "Coordenação de Aperfeiçoamento de Pessoal de Nível Superior - Brasil (CAPES) - Finance Code 001".

\section{Availability of data and materials}

The datasets used and/or analysed during the current study are available from the corresponding author on reasonable request.

\section{Declarations}

Ethics approval and consent to participate

This study was approved by the Research Ethics Committee of the Federal University of Sergipe (CAAE: 15827719.4 .0000 .5546 and protocol number 4.295.171). Pharmacists were informed that their participation was anonymous, voluntary and that their contributions would be confidential. In addition, pharmacists were informed about the objectives of the study and the instructions needed to complete the questionnaire. The names of pharmacists, e-mail and their professional registration numbers were not collected during the survey. Consent was obtained from the participants before completing the survey.

\section{Consent for publication}

Not applicable.

\section{Competing interests}

The authors declare that they have no competing interests.

\section{Author details}

${ }^{1}$ Graduate Program in Pharmaceutical Sciences, Federal University of Sergipe, Avenue Marechal Rondon, Jd. Rosa Elze, São Cristóvão, Sergipe State Zip code 49100-000, Brazil. ' Laboratory of Teaching and Research in Social Pharmacy (LEPFS), Department of Pharmacy, Federal University of Sergipe, Avenue Marechal Rondon, Jd. Rosa Elze, São Cristóvão, Sergipe Zip code 49100-000, Brazil.

Received: 22 October 2021 Accepted: 21 January 2022

Published online: 08 February 2022

\section{References}

1. Salgado TM, Rosenthal MM, Coe AB, Kaefer TN, Dixon DL, Farris KB. Primary healthcare policy and vision for community pharmacy and pharmacists in the United States. Pharm Pract (Granada). 2020;18(3):2160 Available from: https://pharmacypractice.org/journal/index.php/pp/artic le/view/2160.

2. Institute for Human Data Science I. The Global Use of Medicine in 2019 And outlook to 2023. IQVIA Inst Hum Data Sci. 2019. https://www.iqvia. com/insights/the-iqvia-institute/reports/the-global-use-of-medicine-in2019-and-outlook-to-2023. Accessed 20 Aug 2021.

3. Brasil. Conselho Federal de Farmácia. Perfil do farmacêutico no Brasil; 2015. p. 6-8.

4. Brasil. Conselho Federal de Farmácia. Dados 2020. 2020. Available from: https://www.cff.org.br/pagina.php?id=801\&menu=801\&titulo=Dados + 2018 [cited 2020 Jul 19]

5. De Castro MS, Correr CJ. Pharmaceutical care in community pharmacies: practice and research in Brazil. Ann Pharmacother. 2007;41(9):1486-93.

6. Brasil. Presidência da República. Lei n 13.021, de 8 agosto de 2014. Dispõe sobre o exercício e a fiscalização das atividades farmacêuticas. Diário Of da União, Pod Exec Brasília, DF, 8 ago. 2014.

7. WHO. The role of the pharmacist in the health care system. 1994. Available from: https://apps.who.int/iris/handle/10665/59169.

8. Alexander G, Qato D. Ensuring access to medications in the US during the COVID-19 pandemic. JAMA. 2020;324(1):31-2 Available from: https:// pubmed.ncbi.nlm.nih.gov/32271871/.

9. Ung COL. Community pharmacist in public health emergencies: quick to action against the coronavirus 2019-nCoV outbreak. Res Soc Adm Pharm. 2020;16(4):583-6 Available from: https://pubmed.ncbi.nlm.nih.gov/32081 $569 /$.

10. Brasil. Ministério da Saúde. Portaria $n^{\circ}$ 3.916/MS/GM, de 30 de outubro de 1998. Política nacional de medicamentos. Brasília: Diário Oficial da República Federativa do Brasil; 1998. Available from: https://bvsms.saude. gov.br/bvs/saudelegis/gm/1998/prt3916_30_10_1998.html. [cited 2021 Jul 29] 
11. Hernández A, Garcia-Delgado P, Garcia-Cardenas V, Ocaña A, Labrador E, Orera $M L$, et al. Characterization of patients' requests and pharmacists' professional practice in oropharyngeal condition in Spain. Int J Clin Pharm. 2015;37(2):300-9 Available from: https://pubmed.ncbi.nlm.nih. gov/25708123/.

12. NHS - National Health Service. NHS community pharmacy services - a summary. Psnc. 2013; Available from: http://psnc.org.uk/wp-content/ uploads/2013/08/CPCF-summary-July-2013.pdf

13. Payne K, Unni EJ, Jolley B. Impact of dispensing Services in an Independent Community Pharmacy. Pharmacy. 2019;7(2):44.

14. Rajiah K, Sivarasa S, Maharajan MK. Impact of pharmacists' interventions and patients' decision on health outcomes in terms of medication adherence and quality use of medicines among patients attending community pharmacies: a systematic review. Int J Environ Res Public Health. 2021;18(9):4392 Available from: /pmc/articles/PMC8122322/.

15. Alaqeel S, Abanmy NO. Counselling practices in community pharmacies in Riyadh, Saudi Arabia: a cross-sectional study. BMC Health Serv Res. 2015;15:557.

16. Ibrahim MI, Palaian S, Al-Sulaiti F, El-Shami S. Evaluating community pharmacy practice in Qatar using simulated patient method:acute gastroenteritis management. Pharm Pract (Granada). 2016;14(4):800.

17. Do Nascimento Junior J, Paganelli M, Leão Tavares N, Soeiro O, Sarmento CK. Dispensação: dispensar e entregar não são sinônimos. Organ Pan Am Saúde/Organ Mund da Saúde no Bras. 2016;1:1-5 Available from: http:// lattes.cnpq.br/5092973974103229.

18. Zawahir S, Lekamwasam S, Aslani P. Antibiotic dispensing practice in community pharmacies: a simulated client study. Res Soc Adm Pharm. 2019;15(5):584-90 Available from: https://pubmed.ncbi.nlm.nih.gov/ 30093309/.

19. Gonçalves AMRF, Campos MSA, Bernardes A, Gabriel CS, Pereira LRL. Development and validation of an instrument to measure the professional's knowledge of dispensing medication (CDM-51) in community pharmacies. PLoS One. 2020;15(3):e0229855 Available from: https://journ als.plos.org/plosone/article?id=10.1371/journal.pone.0229855.

20. Oliveira NVBV, Szabo I, Bastos LL, Paiva SP. Atuação profissional dos farmacêuticos no brasil: Perfil sociodemográfico e dinâmica de trabalho em farmácias e drogarias privadas. Saude e Soc. 2017;26(4):1105-21.

21. Reis TM, Guidoni CM, Girotto E, Rascado RR, Mastroianni PC, et al. Pharmaceutical care in Brazilian community pharmacies: Knowledge Pract. Afr. J. Pharm. Pharmacol. 2015;9(1):287-94 Available from: http://www.acade micjournals.org/AJPP.

22. Kelley K, Clark B, Brown V, Sitzia J. Good practice in the conduct and reporting of survey research. Int J Qual Health Care. 2003;15(3):261-6.

23. Bennett C, Khangura S, Brehaut JC, Graham ID, Moher D, Potter BK, et al. Reporting guidelines for survey research: an analysis of published guidance and reporting practices. PLoS Med. 2011;8(8):1-11.

24. Rybakov KN, Beckett R, Dilley I, Sheehan AH. Reporting quality of survey research articles published in the pharmacy literature. Res Soc Adm Pharm. 2020:0-1. https://doi.org/10.1016/j.sapharm.2020.01.005.

25. Rocha KSS, Cerqueira Santos S, Boaventura TC, dos Santos Júnior GA, de Araújo DCSA, Silvestre CC, et al. Development and content validation of an instrument to support pharmaceutical counselling for dispensing of prescribed medicines. J Eval Clin Pract. 2020;26(1).

26. Cerqueira-Santos S, Rocha KSS, Boaventura TC, Jesus EMS, Silvestre CC, Alves BMCS, et al. Development and content validation of an instrument to document the dispensing of prescribed medicines. J Clin Pharm Ther. 2019:44(3).

27. Rubio DM, Berg-Weger M, Tebb SS, Lee ES, Rauch S. Objectifying content validity: conducting a content validity study in social work research. Soc Work Res. 2003;27(2):94-104 Available from: https://academic.oup.com/ swr/article/27/2/94/1659075.

28. Fehring RJ. Methods to validate nursing diagnoses. Hear Lung J Crit Care. 1987;16:625-9.

29. Hernández NH. Contributions to statistical analysis: the coefficients of proportional variance, content validity and kappa. 1rd ed. Mérida: Univ Los Andes; 2002.

30. Mirzaei A, Carter SR, Patanwala AE, Schneider CR. Missing data in surveys: Key concepts, approaches, and applications. Res Soc Adm Pharm. 2021. https://doi.org/10.1016/j.sapharm.2021.03.009.
31. Ayalew E, Seid Y, Agalu A. Knowledge, Attitude and practice of patient medication counseling among drug dispensers in Mekele town, Northern Ethiopia; 2015.

32. Surur AS, Getachew E, Teressa E, Hailemeskel B, Getaw NS, Erku DA. Selfreported and actual involvement of community pharmacists in patient counseling: a cross-sectional and simulated patient study in Gondar, Ethiopia. Pharm Pract (Granada). 2017;15(1):1-7.

33. Gelayee DA, Birara MK. Patient Medication Counseling: A Survey of Knowledge, Attitude and Practice of Pharmacy Professionals in Gondar, North West Ethiopia. J Sci Res Pharm. 2015;4(July):74-7.

34. Mesquita AR, De Oliveira Sá DAB, Santos APAL, De Almeida NA, Lyra DP. Assessment of pharmacist's recommendation of non-prescription medicines in Brazil: a simulated patient study. Int J Clin Pharm. 2013;35(4):647-55

35. Mobark DM, Al-Tabakha MM, Hasan S. Assessing hormonal contraceptive dispensing and counseling provided by community pharmacists in the United Arab Emirates: a simulated patient study. Pharm Pract (Granada) 2019;17(2) Available from:/pmc/articles/PMC6594436/.

36. Chong WW, Aslani P, Chen TF. Adherence to antidepressant medications: an evaluation of community pharmacists' counseling practices. Patient Prefer Adherence. 2013;7:813 Available from: /pmc/articles/ PMC3754825/.

37. Brasil. Conselho Federal de Farmácia. Formação Farmacêutica no Brasil/ Conselho Federal de Farmácia. Brasília: Conselho Federal de Farmácia, 2019. Conselho Federal de Farmácia; 2019. p. 160.

38. Brasil. Conselho Regional de Farmácia do Estado de São Paulo. Estudo de Matrizes Curriculares dos Cursos de Farmácia do Estado de São Paulo// Conselho Regional de Farmácia do Estado de São Paulo. São Paulo: Conselho Regional de Farmácia do Estado de São Paulo; 2013. p. 47.

39. Brasil. Câmara de Educação Superior. Resolução CNE-CES Nº 6, de 19 de outubro de 2017. 2017;

40. Foppa AA, Martins GA, Nascimento RF, Mesquita AR, Chemello C. Experiential education in the pharmacy undergraduate curricula in Brazil. Pharmacy Pract. 2020;18(1):1-9.

41. de Sousa Lopes NM, Gondim APS, Soares ACS, dos Santos DB, de Sales Neto MR, Pinto DM. A quantitative analysis of the quality of pharmacy education in Brazil. Am J Pharm Educ. 2019;83(3):6543 Available from: / pmc/articles/PMC6498214/.

42. ACPE Accreditation standards and key elements for the professional program in pharmacy leading to the doctor of pharmacy degree. 2015;

43. APC. Accreditation of pharmacy programs and CPD accrediting organisations | Australian Pharmacy Council. Available from: https://www.pharm acycouncil.org.au/education-provider/accreditation/. [cited 2021 Aug 9]

44. GPhC. Accredited MPharm degrees / General Pharmaceutical Council. Available from: https://www.pharmacyregulation.org/education/appro ved-providers-education-and-training/accredited-mpharm-degrees

45. Aldosari $\mathrm{H}$, Alsairafi Z, Waheedi S. Continuing education in pharmacy: a cross-sectional study exploring pharmacists' attitudes and perceptions. Saudi Pharm J SPJ. 2020;28(7):803 Available from:/pmc/articles/ PMC7335716/.

46. Halila GC, Junior EH, Otuki MF, Correr CJ. The practice of OTC counseling by community pharmacists in Parana. Brazil Pharm Pract (Granada). 2015;13(4):1-8

47. Saade S, Ghazala F, Farhat A, Hallit S. Attitudes towards continuous professional development: a study of pharmacists in Lebanon. Pharm Pract (Granada). 2018;16(1):1103 Available from: /pmc/articles/PMC5881481/.

48. Sacre H, Tawil S, Hallit S, Sili G, Salameh P. Mandatory continuing education for pharmacists in a developing country: assessment of a three-year cycle. Pharm Pract. 2019;17(3) Available from: http://scielo.isciii.es/scielo. php?script $=$ sci_arttext\&pid $=$ S1885-642X2019000300013\&lng $=$ es\& $\mathrm{nrm}=\mathrm{iso} \& \mathrm{tlng}=\mathrm{en}$.

49. Travlos DV, Baumgartner JL, Rouse M, Wadelin JW, Vlasses PH. Forty years of ACPE CPE accreditation. Am J Pharm Educ. 2017;81(9):85-92.

50. Rios MC, Souza WM, Mesquita AR, Cerqueira-santos S, Pereira D, Junior $L$, et al. Assessment of Brazilian pharmacy students ' perception of their level of preparedness for pharmaceutical practice. 2017;11(40):517-25.

51. Schindel TJ, Yuksel N, Breault R, Daniels J, Varnhagen S, Hughes CA. Pharmacists' learning needs in the era of expanding scopes of practice: evolving practices and changing needs. Res Soc Adm Pharm. 2019;15(4):44858. https://doi.org/10.1016/j.sapharm.2018.06.013. 
52. Urbonas G, Kubiliene L. Assessing the relationship between pharmacists' job satisfaction and over-the-counter counselling at community pharmacies. Int J Clin Pharm. 2016;38(2):252-60.

53. Mináriková D, FazekašT, Minárik P, Jurišová E. Assessment of patient counselling on the common cold treatment at Slovak community pharmacies using mystery shopping. Saudi Pharm J. 2019;27(4):574-83.

54. Kaae S, Traulsen JM, Nørgaard LS. Challenges to counseling customers at the pharmacy counter--why do they exist? Res Soc Adm Pharm. 2012;8(3):253-7 Available from: https://pubmed.ncbi.nlm.nih.gov/21955 809/.

55. Seiberth J, Moritz K, Herrmann NS, Bertsche T, Schiek S. What influences the information exchange during self-medication consultations in community pharmacies? Res Social Adm Pharm: A non-participant observation study; 2021. Available from: https://pubmed.ncbi.nlm.nih.gov/33840 622/

56. Maes KA, Jasmine A. Ruppanner, Tamara L, Imfeld-Isenegger KEHEH, Lampert ML, Boeni F. Dispensing of Prescribed Medicines in Swiss Counselling Activities. 2018;1-16.

57. Cerqueira Santos S, Boaventura TC, Rocha KSS, de Oliveira Filho AD, Onozato T, de Lyra DP. Can we document the practice of dispensing? A systematic review. J Clin Pharm Ther. 2016;41(6).

58. Williams M, Peterson G, Tenni P, Bindoff I, Stafford A. DOCUMENT: a system for classifying drug-related problems in community pharmacy. Int J Clin Pharm. 2012;34(1):43-52 Available from: https://pubmed.ncbi.nlm. nih.gov/22101425/.

59. Goals FIPD. FIP digital health in pharmacy education Developing a digitally enabled pharmaceutical workforce 2021 FIP Development Goal 2021; Available from: www.fip.org

60. Lawrence J. Could big data be the future of pharmacy ? promising way to maximise the value of medicines, from identifying poor adherence to improving quality of prescribing; 2018. p. 1-9.

61. Olsson E, Ingman P, Ahmed B, Kälvemark SS. Pharmacist-patient communication in Swedish community pharmacies. Res Soc Adm Pharm. 2014;10(1):149-55 Available from: https://pubmed.ncbi.nlm.nih.gov/ 23591412/.

62. Alam S, Osama M, lqbal S, Sawar I. Reducing pharmacy patient waiting time. Int J Health Care Qual Assur. 2018;31(7):834-44 Available from: https://pubmed.ncbi.nlm.nih.gov/30354876/.

63. Dosea AS, Brito GC, Santos LMC, Marques TC, Balisa-Rocha B, Pimentel $D$, et al. Establishment, implementation, and consolidation of clinical pharmacy Services in Community Pharmacies: perceptions of a Group of Pharmacists. Qual Health Res. 2017:27(3):363-73.

64. Hindi AMK, Schafheutle El, Jacobs S. Patient and public perspectives of community pharmacies in the United Kingdom: a systematic review. Health Expect. 2018;21(2):409-28.

\section{Publisher's Note}

Springer Nature remains neutral with regard to jurisdictional claims in published maps and institutional affiliations.

Ready to submit your research? Choose BMC and benefit from:

- fast, convenient online submission

- thorough peer review by experienced researchers in your field

- rapid publication on acceptance

- support for research data, including large and complex data types

- gold Open Access which fosters wider collaboration and increased citations

- maximum visibility for your research: over $100 \mathrm{M}$ website views per year

At BMC, research is always in progress.

Learn more biomedcentral.com/submissions 